\title{
Reduced Sulfotransferase SULT2A1 Activity in Patients With Alzheimer's Disease
}

\author{
M. VAŇKOVÁ ${ }^{1}$, M. HILL ${ }^{1}$, M. VELÍKOVÁ ${ }^{1}$, J. VČELÁK ${ }^{1}$, G. VACÍNOVÁ ${ }^{1}$, \\ P. LUKÁŠOVÁ ${ }^{1}$, D. VEJRAŽKOVÁ ${ }^{1}$, K. DVOŘÁKOVÁ ${ }^{1}$, R. RUSINA $^{2,4}$, I. HOLMEROVÁ ${ }^{3}$, \\ E. JAROLÍMOVÁ ${ }^{3}$, H. VAŇKOVÁ ${ }^{3,5}$, B. BENDLOVÁ ${ }^{1}$
}

${ }^{1}$ Institute of Endocrinology, Prague, Czech Republic, ${ }^{2}$ Thomayer Hospital, Prague, Czech Republic, ${ }^{3}$ Faculty of Humanities, Charles University, Prague, Czech Republic, ${ }^{4}$ Department of Neurology and Center of Clinical Neuroscience, Charles University in Prague, First Faculty of Medicine and General University Hospital in Prague, Czech Republic, ${ }^{5}$ Third Faculty of Medicine, Charles University in Prague, Czech Republic

Received August 2, 2015

Accepted August 18, 2015

\section{Summary}

Steroids are important components in the pathophysiology of Alzheimer's disease (AD). Although their role has been studied, the corresponding metabolomic data is limited. In the present study we evaluate the role of steroid sulfotransferase SULT2A1 in the pathophysiology of $A D$ on the basis of circulating steroids (measured by GC-MS), in which the sulfation catalyzed by SULT2A1 dominates over glucuronidation (pregnenolone/sulfate, DHEA/sulfate, androstenediol/sulfate and 5a-reduced pregnane and androstane catabolites). To estimate a general trend of SUL2A1 activity in AD patients we compared the ratios of steroid conjugates to their unconjugated counterparts $(C / U)$ in controls (11 men and 22 women) and $A D$ patients (18 men and 16 women) for individual circulating steroids after adjustment for age and BMI using ANCOVA model including the factors $A D$ status and gender. Decreased C/U ratio for the $\mathrm{C} 19$ steroids demonstrate an association between attenuated sulfation of C19 steroids in adrenal zona reticularis and the pathophysiology of $A D$.

\section{Key words}

Alzheimer's disease • SULT2A1 • GC-MS • Steroids

\section{Corresponding author}

M. Vaňková, Department of Molecular Endocrinology, Institute of Endocrinology, Národní 8, Prague, 116 94, Czech Republic. E-mail: mvankova@endo.cz

\section{Introduction}

Alzheimer's disease (AD) represents more than one half of total dementias in seniors. The number of people living with dementia worldwide today is estimated at 44 million, set to almost double by 2030 and more than triple by 2050 (Prince et al. 2014).

$\mathrm{AD}$ is a neurodegenerative disease with progressive decline of episodic memory and impairment in other cognitive domains leading to dementia with loss of autonomy. Definite diagnosis of $\mathrm{AD}$ requires neuropathological confirmation from autopsy. Current diagnostic criteria for AD are mainly based on clinical and neuropsychological assessment (McKhann et al. 2011).

There is increasing evidence that pathological processes in the brain of AD patients may begin even 10-20 years before the first symptoms appear (Holtzman et al. 2011), therefore, the need for early diagnosis is important and other biomarkers may be useful.

Various factors including altered steroid biosynthesis may participate in the pathophysiology of AD. Steroid hormones are effective regulators of many physiological processes, including those in the brain (Hampl and Bicikova 2010). Steroid hormones active in neural tissue are neuroactive steroids, which arise in the gonads (in women only in the reproductive period) and in the adrenal glands (the main source of postmenopausal women) and into the central nervous system are 
transported across the blood-brain barrier directly or in the form of precursors. However, a small portion of steroids, called neurosteroids, are produced directly in nervous tissue. The peripheral steroidogenesis may substantially influence neuronal activity in the brain.

Age-related deficit of sex steroid hormones increases the risk of dysfunction in hormone-responsive tissues, including brain. Age-dependent hormone depletion in the brain may result in diminished neuroprotection, which increases a risk of neurodegenerative diseases such as $\mathrm{AD}$ (Rosario and Pike 2008). AD is more prevalent in women, which may be explained by differences in life expectancy in women compared to men. However, incidence of $\mathrm{AD}$ is also higher in women (Ruitenberg et al. 2001). Nevertheless, the basis of higher vulnerability for females to $\mathrm{AD}$ remains unclear.

From the menopause, dehydroepiandrosterone (DHEA) remains the exclusive and adrenal tissue-specific source of sex steroids in women while in (65-75 year-old) men, the contribution of adrenal DHEA to the total androgens is approximately $40 \%$ (Labrie 2010). Sex steroid hormones derived from DHEA show a similar decline from the age of 30 years in both genders, but there is a continuous supply of testosterone, estrone and estradiol from testes in men. The ovarian estradiol secretion in women ends at the menopause.

Age-related loss of sex steroid hormones is associated with numerous diseases such as tissue atrophy, bone loss, fat accumulation, type 2 diabetes mellitus, and also with cognition problems, memory loss and perhaps with AD (Labrie 2007). Alterations in steroid biosynthesis may contribute to the pathology of AD (Liu et al. 2013, Napolitano et al. 2014, Schumacher et al. 2014, Winkler and Fox 2013).

The endogenous sex steroids, estrogens, androgens, and progesterone, have effects on the brain, especially in perimenopausal and postmenopausal women (Yaffe et al. 2000). DHEA, which may be converted to estrogens locally in the brain, have been shown to enhance memory and learning functions (Vallee et al. 2001). Similarly, DHEA sulfate (DHEAS) influences brain function and affects memory capacity (Hunt $e t$ al. 2000). DHEA acting in the brain is either of peripheral origin, or may be synthesized directly in the brain and may be also converted into estrogens or androgens in brain tissues. Various brain areas express nuclear receptors for estrogens, androgens and progesterone. Besides the nuclear receptors, both androstane and pregnane steroids may also modulate the permeability of various ion channels such as excitatory glutamate receptors on one hand or inhibitory gamma-aminobutyric acid (GABA) receptors on the other hand (Bergeron et al. 1996, Majewska et al. 1990, Hill et al. 2015, Starka et al. 2015).

Steroid sulfates having distinct physiological role compared with their unconjugated counterparts are important precursors of further bioactive steroids (Strott 2002). The circulating levels of conjugated steroids are usually much higher than in their non-conjugated forms. The steroid conjugates are frequently metabolic endproducts with excellent water solubility enabling their uncomplicated excretion into the urine. The conjugation generally alters biological activity (Strott 1996) and may even convert the unconjugated steroids to their biological antagonists (Park-Chung et al. 1997, 1999). Even though the sulfotransferase activity in primate brain is low (Kriz et al. 2005), the sulfation of brain neurosteroids might participate on the maintenance of brain function. Steroid sulfates are bound to serum proteins such as albumin, corticosteroid binding globulin (CBG), and sex hormone binding globulin (SHBG), and serve as circulating reservoir, while non-conjugated forms are more active at the tissue level.

Human SULT2A1 (sulfotransferase family 2A, dehydroepiandrosterone-preferring, member 1) is enzyme strongly expressed in fetal zone of the fetal adrenal gland (Barker et al. 1994), and in the zona reticularis of the mature adrenal gland. Besides the primary source of steroid sulfotransferase activity in adrenal zona reticularis, also the kidneys and small intestine exhibit significant sulfotransferase activities (Barker et al. 1994, Otterness et al. 1992). SULT2A1 expression is also detectable in ovary and prostate, in stomach and colon (Javitt et al. 2001), but these tissues produce the enzyme at a lower levels (Shimada et al. 2001). Besides the DHEA, the SULT2A1 catalyzes the sulfation of further androgens, their $5 \alpha / \beta$-reduced catabolites, pregnenolone, $5 \alpha / \beta$-reduced pregnanolone isomers and pregnanediols, and also the bile acids. Whereas the lower ratio of circulating sulfates to unconjugated form of steroids may indicate the lower overall SULT2A1 activity, we attempted to investigate whether the reduced ratios of steroid sulfates to their unconjugated counterparts are consistently lower in the $\mathrm{AD}$ and if so, whether these ratios may be used as markers of $\mathrm{AD}$. 


\section{Materials and Methods}

\section{Subjects}

A total of 34 patients with $\mathrm{AD}$ (16 women and 18 men) fulfilling NINCDS-ADRDA criteria (National Institute of Neurological Communicative Disorders and Stroke - Alzheimer's disease and Related Disorders Association) for probable Alzheimer's disease and 33 controls of similar age as the patients (22 women and 11 men) participated in the study (Table 1).

Diagnosis of $\mathrm{AD}$ was confirmed by neuropsychological tests (Repeatable Battery for the Assessment of Neuropsychological Status, Montreal
Cognitive Assessment, and Geriatric Depression Scale), biochemical examination of cerebrospinal fluid ( $\beta$-amyloid peptides, total and phosphorylated $\tau$-proteins) and magnetic resonance imaging of the brain. In our cohort of patients, 25 patients had AD, 3 patients had possible dementia with Lewy bodies in comorbidity and 6 patients had $\mathrm{AD}$ and significant subcortical ischemic white matter lesions consistent with the diagnosis of mixed dementia. Controls were examined with the same neuropsychological battery and had magnetic resonance imaging of the brain but lumbar puncture was not performed in these subjects.

Table 1. Comparison of anthropometric and biochemical characteristics in controls and in patients with Alzheimer's disease (AD).

\begin{tabular}{lccc}
\hline & \multicolumn{2}{c}{ Mean (95\% confidence limits) } & ANOVA \\
\cline { 2 - 4 } Variable & Controls & AD patients & $\boldsymbol{p}$ \\
\hline Women & $\mathbf{n}=\mathbf{2 2}$ & $\mathbf{n}=\mathbf{1 6}$ & \\
Age (years) & $66.9(65.1,68.8)$ & $74.8(72.1,77.7)$ & $\mathbf{0 . 0 0 1}$ \\
BMI $\left(\mathrm{kg} / \mathrm{m}^{2}\right)$ & $24.9(23.6,26.4)$ & $27.7(25.8,29.8)$ & 0.123 \\
WHR & $0.81(0.79,0.83)$ & $0.84(0.82,0.87)$ & 0.172 \\
BAI & $32.3(30.7,34.1)$ & $31.7(29.8,33.7)$ & 0.758 \\
HbAlc (\%) & $39.3(37.9,40.7)$ & $35.2(33.4,36.9)$ & $\mathbf{0 . 0 1 6}$ \\
Total cholesterol (mmol/l) & $5.03(4.77,5.31)$ & $5.55(5.19,5.97)$ & 0.134 \\
HDL-cholesterol (mmol/l) & $1.53(1.4,1.66)$ & $1.75(1.58,1.94)$ & 0.179 \\
LDL-cholesterol (mmol/l) & $2.89(2.6,3.19)$ & $3.25(2.9,3.63)$ & 0.295 \\
Triacylglycerols $(\mathrm{mmol} / \mathrm{l})$ & $1.14(1.01,1.3)$ & $1.08(0.945,1.26)$ & 0.743 \\
Men & $\mathbf{n}=\mathbf{1 1}$ & $\mathbf{n}=\mathbf{1 8}$ & \\
Age (years) & $68.8(64.5,73.1)$ & $72.5(69.2,75.8)$ & 0.327 \\
BMI $\left(\mathrm{kg} / \mathrm{m}^{2}\right)$ & $27.2(25.7,28.8)$ & $26.1(25,27.2)$ & 0.393 \\
WHR & $0.95(0.92,0.99)$ & $0.93(0.91,0.96)$ & 0.457 \\
BAI & $26.2(25.1,27.3)$ & $26.3(25.4,27.2)$ & 0.914 \\
HbAlc (\%) & $38(36.3,39.6)$ & $38.1(36.8,39.5)$ & 0.904 \\
Total cholesterol (mmol/l) & $4.58(4.13,5.11)$ & $4.55(4.2,4.95)$ & 0.94 \\
HDL-cholesterol (mmol/l) & $1.42(1.32,1.52)$ & $1.31(1.23,1.39)$ & 0.24 \\
LDL-cholesterol (mmol/l) & $2.57(2.21,3.02)$ & $2.68(2.37,3.04)$ & 0.771 \\
Triacylglycerols (mmol/l) & $1.11(0.911,1.34)$ & $1.17(1,1.36)$ & 0.756 \\
\hline
\end{tabular}

The study subjects, patients as well as controls, did not use any drug known to interfere with the steroid biosynthesis and catabolism, especially corticoids, selective serotonin reuptake inhibitors, estrogens, hormone replacement therapy and nonsteroidal antiinflammatory drugs.

Participants were examined after signing an informed consent approved by the Ethics Committee of the Institute of Endocrinology. For the evaluation of basic biochemical parameters and steroid metabolome, $10 \mathrm{ml}$ of blood was withdrawn on fasting in the morning. Blood samples were centrifuged and stored at $-80{ }^{\circ} \mathrm{C}$ until analyzed.

Anthropometric measurements

The waist to hip ratio (WHR) and body mass 
index (BMI) were calculated. Body adiposity index (BAI), a surrogate measure of body fat, was calculated as described elsewhere (Freedman et al. 2012).

\section{Analytical methods}

The circulating levels of steroids and their polar conjugates were simultaneously measured using the previously described gas chromatography-mass spectrometry (GC-MS) method (Hill et al. 2010). In brief, the $1 \mathrm{ml}$ of serum was extracted by $3 \mathrm{ml}$ of diethyl-ether. The dry residue from the organic layer was partitioned between $1 \mathrm{ml}$ of pentane and $1 \mathrm{ml}$ of $80 \%$ methanol-water mixture and the dry residue from the methanol-water layer was derivatized by $2 \%$ of methoxylamine-hydrochloride in pyridine and then silylated by N,OBis(trimethylsilyl)trifluoroacetamide with $1 \%$ of trimethylchlorosilane. The polar layer from the diethylether extraction was hydrolyzed using the method by Dehennin et al. (1996) and then processed like the unconjugated steroids. Steroid polar conjugates contain mainly sulfates and glucuronides. In this study, we focused on the steroids in which the sulfates dominate over glucuronides such as $\Delta^{5}$ steroids (adrenal gland pathway) and $5 \alpha$-reduced C21 and C19 steroid metabolites.

Triacylglycerols, total cholesterol, and HDLcholesterol were assayed by enzymatic colorimetric test, glycated hemoglobin A1c (HbA1c) was assayed by turbidimetric inhibition method (Roche, Cobas 6000). LDL-cholesterol was calculated as total cholesterol minus (triacylglycerols divided by 2.2) minus HDL-cholesterol.

\section{Statistical analysis}

Respecting the skewed distribution and nonconstant variance in most dependent variables, these were transformed by power transformations to data symmetry and homoscedasticity prior further processing (Meloun $e t$ al. 2000). The homogeneity and distribution of the transformed data was checked by residual analysis as described elsewhere (Meloun et al. 2002).

To correctly explain the relationships between steroids, than product to precursor ratio (sulfates to unconjugated steroids ratio) and presence of $\mathrm{AD}$ for both genders, we used age- and BMI-adjusted ANCOVA with factors $\mathrm{AD}$ and gender. Anthropometric characteristics were evaluated using one-way ANOVA. Statistical software Statgraphics Centurion, version XV from Statpoint Inc. (Herndon, Virginia, USA) was used for ANOVA and ANCOVA testing.

\section{Results}

The differences between the ratios of conjugated to unconjugated steroids $(\mathrm{C} / \mathrm{U})$ in $\mathrm{AD}$ patients and controls with respect to gender are shown in Table 2.

As illustrated in Table 2, the $\mathrm{C} / \mathrm{U}$ of the $\mathrm{C} 21$ steroids do not exhibit significant alterations in $\mathrm{AD}$ patients. On the other hand, the $\mathrm{C} / \mathrm{U}$ of the $\Delta^{5} \mathrm{C} 19$ steroid DHEA and its $5 \alpha$-reduced metabolites with a dominance of sulfates over the glucuronides (androsterone, epiandrosterone, $5 \alpha$-androstane- $3 \alpha, 17 \beta$-diol, $5 \alpha$-androstane-3 $\beta, 17 \beta$-diol) are consistently lower in $A D$ patients. Some $C / U$ are significantly higher in men (pregnenolone, isopregnanolone, DHEA, epiandrosterone, $5 \alpha$-androstane- $3 \alpha, 17 \beta$-diol) and the $\mathrm{C} / \mathrm{U}$ in the androsterone negatively correlate with age. BMI do not significantly influence the values of $\mathrm{C} / \mathrm{U}$.

\section{Discussion}

Steroids are recognized as important components in the pathophysiology of AD. Although their role has been widely studied, the corresponding metabolomic data are limited (Maggio et al. 2015). To our knowledge, this study is the first attempt to evaluate the role of steroid sulfotransferase SULT2A1 in the pathophysiology of AD on the basis of steroid metabolome in the circulation. For this purpose we have selected the unconjugated steroids and their conjugated counterparts in which the sulfation catalyzed by SULT2A1 dominates over glucuronidation. Therefore we omit the $5 \beta$-reduced steroids, in which the glucuronidation is comparable with sulfation (Brochu and Belanger 1987). Furthermore, estrogens, which are extensively sulfated by estrogen preferring sulfotransferase SULT1E1, are also omitted (Tibbs et al. 2015). To estimate a general trend of SULT2A1 activity in $\mathrm{AD}$ patients, we have compared the ratios of steroid conjugates to their unconjugated counterparts $(\mathrm{C} / \mathrm{U})$ in controls and $\mathrm{AD}$ patients for individual circulating steroids after adjustment for age and BMI using the ANCOVA model.

Our results showing decreased $\mathrm{C} / \mathrm{U}$ in the $\mathrm{C} 19$ steroids demonstrate at least an association between attenuated sulfation of C19 steroids in adrenal zona reticularis and the pathophysiology of $\mathrm{AD}$. These data are compatible with the concept of "older" zona reticularis in $\mathrm{AD}$ patients compared with controls. Numerous studies demonstrate decline in adrenal androgen production with advancing age and an 


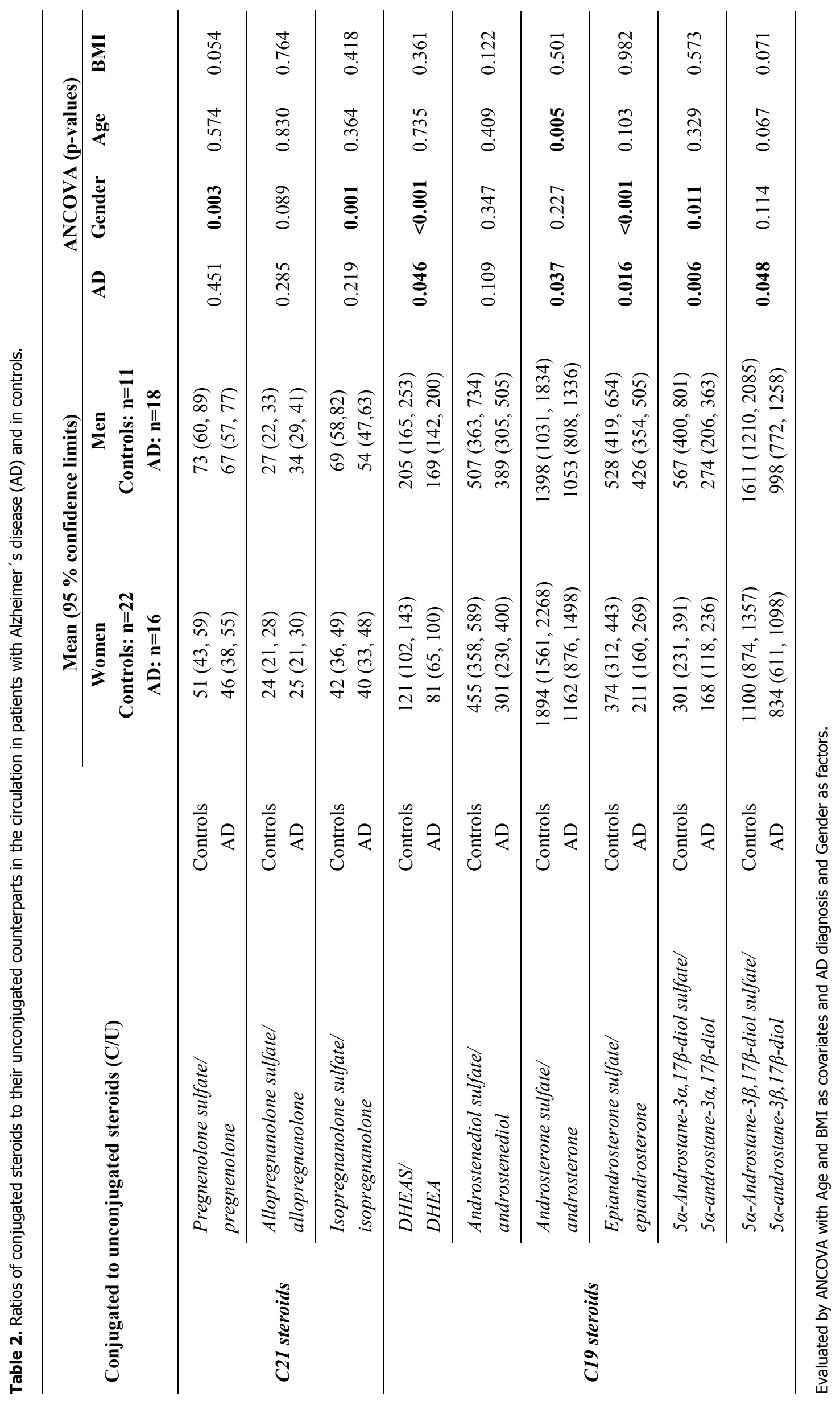


analogous diminution in the area represented by the zona reticularis, which is regulated by extra-adrenal modulators such as corticoliberin, adrenocorticotropic hormone, insulin, and transforming growth factor $\beta$ (Auchus 2004, Dharia and Parker 2004, Ibanez et al. 1999, Sulcova et al. 1997). Although the DHEA is unlikely to have influence on the cognitive abilities in AD patients (Maggio et al. 2015), a variety of studies demonstrate higher prevalence of degenerative disorders, including $\mathrm{AD}$, and other report neuro-protective and antiaging effects of DHEA/DHEAS and possible corresponding mechanisms of DHEA/DHEAS actions (Hildreth et al. 2013, Lu et al. 2003, Traish et al. 2011, Hill et al. 2014a, Maggio et al. 2015, Starka et al. 2015). Furthermore, adrenal androgens serve as precursors of potent androgens or estrogens in target tissues (Labrie 2003).

Our results are in accordance with previous data indicating attenuated activity of zona reticularis in $\mathrm{AD}$ (Aldred and Mecocci 2010, Bernardi et al. 2000, Hillen et al. 2000, Kim et al. 2003, Nasman et al. 1991, WeillEngerer et al. 2002). Furthermore, some authors report attenuated levels of adrenal androgens in C19 steroids and particularly their sulfates in body fluids and brain tissues of AD patients (Yanase et al. 1996) and others report lower DHEAS levels in subjects in which the AD developed during the prospective study. The latter authors also suggest the attenuated activity of zona reticularis as an important factor in the pathophysiology of AD (Ponholzer et al. 2009).

Concerning the extra-adrenal factors influencing the balance between sulfated and unconjugated steroids, SULT2A1 is also highly expressed in the liver and have an important detoxification function in the liver metabolism. Patients suffering from some liver disorders such as alcohol cirrhosis exhibit suppressed SULT2A1 activity (Yalcin et al. 2013). Decreased SULT2A1 activity was also described in human with acute sepsis (Kim et al. 2004). However, none of volunteers included in our study suffered from these pathologies. Regarding the effect of polymorphisms in SULT2A1 gene on the balance between sulfated and unconjugated steroids, some studies report no such association in healthy subjects from the general population (Goodarzi et al. 2007, Haring et al. 2013).

The certain contradiction of the study is the absence of analogous significant between group differences in the $\mathrm{C} / \mathrm{U}$ of $\mathrm{C} 21$ steroids, which might be ascribed to lower stability in the case of C21 $\Delta^{5}$ steroids as the pregnenolone and its sulfate are the precursors of all remaining steroids and undergo a rapid metabolism with high inter-individual variation in individual metabolic steps, while the sulfates of C19-steroids and particularly of their $5 \alpha$-reduced catabolites are more stable. The absence of significant between group differences in the $\mathrm{C} / \mathrm{U}$ of $5 \alpha$-reduced pregnanolone isomers and allopregnanolone of $\mathrm{AD}$ may be explained by an effect of inter-individual variability in further metabolism of these steroids to the corresponding sulfated pregnanediols, which are end products of progesterone catabolism.

Some steroid $\mathrm{C} / \mathrm{U} \quad$ (pregnenolone, isopregnanolone, DHEA, epiandrosterone and $5 \alpha$-androstane- $3 \alpha, 17 \beta$-diol) are higher in men, perhaps due to influence of testicular steroidogenesis on the balance between sulfated and unconjugated forms of the steroids. The $\mathrm{C} / \mathrm{U}$ investigated mostly do not correlate with age except the $\mathrm{C} / \mathrm{U}$ for androsterone, which may be ascribed to relative homogeneity of the sample as concerns the age. This may be also the reason why BMI does not significantly influence the values of the steroid $\mathrm{C} / \mathrm{U}$.

In conclusion, the present study demonstrating an association between attenuated sulfation of C19 steroids in adrenal zona reticularis and the pathophysiology of $\mathrm{AD}$ is compatible with the concept of "older" zona reticularis in $\mathrm{AD}$ patients compared with controls.

\section{Conflict of Interest}

There is no conflict of interest.

\section{Acknowledgements}

This study was supported by the Grant IGA NT/13543-4 of the Czech Ministry of Health.

\section{Abbreviations}

AD, Alzheimer's disease; ANCOVA, analysis of covariance; ANOVA, analysis of variance; BAI, body adiposity index; BMI, body mass index; $\mathrm{CBG}$, corticosteroid binding globulin; $\mathrm{C} / \mathrm{U}$, conjugates to unconjugated counterparts ratio; $\mathrm{C} 19, \mathrm{C} 21$, carbon number of steroid; DHEA, dehydroepiandrosterone; DHEAS, dehydroepiandrosterone sulfate; GABA, gamma-aminobutyric acid; GC-MS, gas chromatographymass spectrometry; HbAlc, glycated hemoglobin (A1c); HDL, high density lipoprotein; LDL, low density lipoprotein; SHBG, sex hormone binding globulin; 
SULT2A1, sulfotransferase family 2A, SULT1E1, sulfotransferase family 1E, estrogendehydroepiandrosterone preferring, member 1; preferring, member 1; WHR, waist to hip ratio.

\section{References}

ALDRED S, MECOCCI P: Decreased dehydroepiandrosterone (DHEA) and dehydroepiandrosterone sulfate (DHEAS) concentrations in plasma of Alzheimer's disease (AD) patients. Arch Gerontol Geriatr 51: e16-e18, 2010.

AUCHUS RJ: Overview of dehydroepiandrosterone biosynthesis. Semin Reprod Med 22: 281-288, 2004.

BARKER EV, HUME R, HALLAS A, COUGHTRIE WH: Dehydroepiandrosterone sulfotransferase in the developing human fetus: quantitative biochemical and immunological characterization of the hepatic, renal, and adrenal enzymes. Endocrinology 134: 982-989, 1994.

BERGERON R, DE MONTIGNY C, DEBONNEL G: Potentiation of neuronal NMDA response induced by dehydroepiandrosterone and its suppression by progesterone: effects mediated via sigma receptors. $J$ Neurosci 16: 1193-1202, 1996.

BERNARDI F, LANZONE A, CENTO RM, SPADA RS, PEZZANI I, GENAZZANI AD, LUISI S, LUISI M, PETRAGLIA F, GENAZZANI AR: Allopregnanolone and dehydroepiandrosterone response to corticotropinreleasing factor in patients suffering from Alzheimer's disease and vascular dementia. Eur J Endocrinol 142: 466-471, 2000.

BROCHU M, BELANGER A: Increase in plasma steroid glucuronide levels in men from infancy to adulthood. $J$ Clin Endocrinol Metab 64: 1283-1287, 1987.

DEHENNIN L, LAFARGE P, DAILLY P, BAILLOUX D, LAFARGE JP: Combined profile of androgen glucuro- and sulfoconjugates in post-competition urine of sportsmen: a simple screening procedure using gas chromatography-mass spectrometry. J Chromatogr B Biomed Appl 687: 85-91, 1996.

DHARIA S, PARKER CR JR: Adrenal androgens and aging. Semin Reprod Med 22: 361-368, 2004.

FREEDMAN DS, THORNTON JC, PI-SUNYER FX, HEYMSFIELD SB, WANG J, PIERSON RN JR, BLANCK HM, GALLAGHER D: The body adiposity index (hip circumference/height(1.5)) is not a more accurate measure of adiposity than is BMI, waist circumference, or hip circumference. Obesity (Silver Spring) 20: 24382444, 2012.

GOODARZI MO, ANTOINE HJ, AZZIZ R: Genes for enzymes regulating dehydroepiandrosterone sulfonation are associated with levels of dehydroepiandrosterone sulfate in polycystic ovary syndrome. $J$ Clin Endocrinol Metab 92: 2659-2664, 2007.

HAMPL R, BICIKOVA M: Neuroimmunomodulatory steroids in Alzheimer dementia. J Steroid Biochem Mol Biol 119: 97-104, 2010.

HARING R, WALLASCHOFSKI H, TEUMER A, KROEMER H, TAYLOR AE, SHACKLETON CH, NAUCK M, VOLKER U, HOMUTH G, ARLT W: A SULT2A1 genetic variant identified by GWAS as associated with low serum DHEAS does not impact on the actual DHEA/DHEAS ratio. J Mol Endocrinol 50: 73-77, 2013.

HILDRETH KL, GOZANSKY WS, JANKOWSKI CM, GRIGSBY J, WOLFE P, KOHRT WM: Association of serum dehydroepiandrosterone sulfate and cognition in older adults: sex steroid, inflammatory, and metabolic mechanisms. Neuropsychology 27: 356-363, 2013.

HILL M, PARIZEK A, KANCHEVA R, DUSKOVA M, VELIKOVA M, KRIZ L, KLIMKOVA M, PASKOVA A, ZIZKA Z, MATUCHA P, MELOUN M, STARKA L: Steroid metabolome in plasma from the umbilical artery, umbilical vein, maternal cubital vein and in amniotic fluid in normal and preterm labor. $J$ Steroid Biochem Mol Biol 121: 594-610, 2010.

HILL M, DUŠKOVÁ M, STARKA L: Dehydroepiandrosterone, its metabolites and ion channels. J Steroid Biochem Mol Biol 145: 293-314, 2015.

HILLEN T, LUN A, REISCHIES FM, BORCHELT M, STEINHAGEN-THIESSEN E, SCHAUB RT: DHEA-S plasma levels and incidence of Alzheimer's disease. Biol Psychiatry 47: 161-163, 2000.

HOLTZMAN DM, MORRIS JC, GOATE AM: Alzheimer's disease: the challenge of the second century. Sci Transl Med 3: 77sr1, 2011. 
HUNT PJ, GURNELL EM, HUPPERT FA, RICHARDS C, PREVOST AT, WASS JA, HERBERT J, CHATTERJEE VK: Improvement in mood and fatigue after dehydroepiandrosterone replacement in Addison's disease in a randomized, double blind trial. J Clin Endocrinol Metab 85: 4650-4656, 2000.

IBANEZ L, POTAU N, MARCOS MV, DE ZEGHER F: Corticotropin-releasing hormone as adrenal androgen secretagogue. Pediatr Res 46: 351-353, 1999.

JAVITT NB, LEE YC, SHIMIZU C, FUDA H, STROTT CA: Cholesterol and hydroxycholesterol sulfotransferases: identification, distinction from dehydroepiandrosterone sulfotransferase, and differential tissue expression. Endocrinology 142: 2978-2984, 2001.

KIM SB, HILL M, KWAK YT, HAMPL R, JO DH, MORFIN R: Neurosteroids: Cerebrospinal fluid levels for Alzheimer's disease and vascular dementia diagnostics. J Clin Endocrinol Metab 88: 5199-5206, 2003.

KIM MS, SHIGENAGA J, MOSER A, GRUNFELD C, FEINGOLD KR: Suppression of DHEA sulfotransferase (Sult2A1) during the acute-phase response. Am J Physiol Endocrinol Metab 287: E731-E738, 2004.

KRIZ L, BICIKOVA M, HILL M, HAMPL R: Steroid sulfatase and sulfuryl transferase activity in monkey brain tissue. Steroids 70: 960-969, 2005.

LABRIE F: Extragonadal synthesis of sex steroids: intracrinology. Ann Endocrinol (Paris) 64: 95-107, 2003.

LABRIE F: Drug insight: breast cancer prevention and tissue-targeted hormone replacement therapy. Nat Clin Pract Endocrinol Metab 3: 584-593, 2007.

LABRIE F: DHEA, important source of sex steroids in men and even more in women. Prog Brain Res 182: 97-148, 2010.

LIU S, WU H, XUE G, MA X, WU J, QIN Y, HOU Y: Metabolic alteration of neuroactive steroids and protective effect of progesterone in Alzheimer's disease-like rats. Neural Regen Res 8: 2800-2810, 2013.

LU SF, MO Q, HU S, GARIPPA C, SIMON NG: Dehydroepiandrosterone upregulates neural androgen receptor level and transcriptional activity. J Neurobiol 57: 163-171, 2003.

MAGGIO M, DE VITA F, FISICHELLA A, COLIZZI E, PROVENZANO S, LAURETANI F, LUCI M, CERESINI G, DALL'AGLIO E, CAFFARRA P, VALENTI G, CEDA GP: DHEA and cognitive function in the elderly. J Steroid Biochem Mol Biol 145: 281-292, 2015.

MAJEWSKA MD, DEMIRGOREN S, SPIVAK CE, LONDON ED: The neurosteroid dehydroepiandrosterone sulfate is an allosteric antagonist of the GABAA receptor. Brain Res 526: 143-146, 1990.

MCKHANN GM, KNOPMAN DS, CHERTKOW H, HYMAN BT, JACK CR JR, KAWAS CH, KLUNK WE, KOROSHETZ WJ, MANLY JJ, MAYEUX R, MOHS RC, MORRIS JC, ROSSOR MN, SCHELTENS P, CARRILLO MC, THIES B, WEINTRAUB S, PHELPS CH: The diagnosis of dementia due to Alzheimer's disease: recommendations from the National Institute on Aging-Alzheimer's Association workgroups on diagnostic guidelines for Alzheimer's disease. Alzheimers Dement 7: 263-269, 2011.

MELOUN M, HILL M, MILITKY J, KUPKA K: Transformation in the PC-aided biochemical data analysis. Clin Chem Lab Med 38: 553-559, 2000.

MELOUN M, MILITKY J, HILL M, BRERETON RG: Crucial problems in regression modelling and their solutions. Analyst 127: 433-450, 2002.

NAPOLITANO M, COSTA L, PIACENTINI R, GRASSI C, LANZONE A, GULINO A: 17beta-estradiol protects cerebellar granule cells against beta-amyloid-induced toxicity via the apoptotic mitochondrial pathway. Neurosci Lett 561: 134-139, 2014.

NASMAN B, OLSSON T, BACKSTROM T, ERIKSSON S, GRANKVIST K, VIITANEN M, BUCHT G: Serum dehydroepiandrosterone sulfate in Alzheimer's disease and in multi-infarct dementia. Biol Psychiatry 30: 684-690, 1991.

OTTERNESS DM, WIEBEN ED, WOOD TC, WATSON WG, MADDEN BJ, MCCORMICK DJ, WEINSHILBOUM RM: Human liver dehydroepiandrosterone sulfotransferase: molecular cloning and expression of cDNA. Mol Pharmacol 41: 865-872, 1992.

PARK-CHUNG M, WU FS, PURDY RH, MALAYEV AA, GIBBS TT, FARB DH: Distinct sites for inverse modulation of N-methyl-D-aspartate receptors by sulfated steroids. Mol Pharmacol 52: 1113-1123, 1997.

PARK-CHUNG M, MALAYEV A, PURDY RH, GIBBS TT, FARB DH: Sulfated and unsulfated steroids modulate gamma-aminobutyric acidA receptor function through distinct sites. Brain Res 830: 72-87, 1999. 
PONHOLZER A, MADERSBACHER S, RAUCHENWALD M, JUNGWIRTH S, FISCHER P, TRAGL KH: Serum androgen levels and their association to depression and Alzheimer dementia in a cohort of 75-year-old men over 5 years: results of the VITA study. Int J Impot Res 21: 187-191, 2009.

PRINCE M, ALBANESE E, GUERCHET M, PRINA M: World Alzheimer Report 2014. Alzheimer's Disease International, London, UK, 2014, pp 1-99.

ROSARIO ER, PIKE CJ: Androgen regulation of beta-amyloid protein and the risk of Alzheimer's disease. Brain Res Rev 57: 444-453, 2008.

RUITENBERG A, OTT A, VAN SWIETEN JC, HOFMAN A, BRETELER MM: Incidence of dementia: does gender make a difference? Neurobiol Aging 22: 575-580, 2001.

SCHUMACHER M, MATTERN C, GHOUMARI A, OUDINET JP, LIERE P, LABOMBARDA F, SITRUK-WARE R, DE NICOLA AF, GUENNOUN R: Revisiting the roles of progesterone and allopregnanolone in the nervous system: resurgence of the progesterone receptors. Prog Neurobiol 113: 6-39, 2014.

SHIMADA M, YOSHINARI K, TANABE E, SHIMAKAWA E, KOBASHI M, NAGATA K, YAMAZOE Y: Identification of ST2A1 as a rat brain neurosteroid sulfotransferase mRNA. Brain Res 920: 222-225, 2001.

STARKA L, DUSKOVA M, HILL M: Dehydroepiandrosterone: a neuroactive steroid. J Steroid Biochem Mol Biol 145: 254-260, 2015.

STROTT CA: Steroid sulfotransferases. Endocr Rev 17: 670-697, 1996.

STROTT CA: Sulfonation and molecular action. Endocr Rev 23: 703-732, 2002.

SULCOVA J, HILL M, HAMPL R, STARKA L: Age and sex related differences in serum levels of unconjugated dehydroepiandrosterone and its sulphate in normal subjects. J Endocrinol 154: 57-62, 1997.

TIBBS ZE, ROHN-GLOWACKI KJ, CRITTENDEN F, GUIDRY AL, FALANY CN: Structural plasticity in the human cytosolic sulfotransferase dimer and its role in substrate selectivity and catalysis. Drug Metab Pharmacokinet 30: 3-20, 2015.

TRAISH AM, KANG HP, SAAD F, GUAY AT: Dehydroepiandrosterone (DHEA) - a precursor steroid or an active hormone in human physiology. J Sex Med 8: 2960-2982; quiz 2983, 2011.

VALLEE M, MAYO W, LE MOAL M: Role of pregnenolone, dehydroepiandrosterone and their sulfate esters on learning and memory in cognitive aging. Brain Res Brain Res Rev 37: 301-312, 2001.

WEILL-ENGERER S, DAVID JP, SAZDOVITCH V, LIERE P, EYCHENNE B, PIANOS A, SCHUMACHER M, DELACOURTE A, BAULIEU EE, AKWA Y: Neurosteroid quantification in human brain regions: comparison between Alzheimer's and nondemented patients. J Clin Endocrinol Metab 87: 5138-5143, 2002.

WINKLER JM, FOX HS: Transcriptome meta-analysis reveals a central role for sex steroids in the degeneration of hippocampal neurons in Alzheimer's disease. BMC Syst Biol 7: 51, 2013.

YAFFE K, LUI LY, GRADY D, CAULEY J, KRAMER J, CUMMINGS SR: Cognitive decline in women in relation to non-protein-bound oestradiol concentrations. Lancet 356: 708-712, 2000.

YALCIN EB, MORE V, NEIRA KL, LU ZJ, CHERRINGTON NJ, SLITT AL, KING RS: Downregulation of sulfotransferase expression and activity in diseased human livers. Drug Metab Dispos 41: 1642-1650, 2013.

YANASE T, FUKAHORI M, TANIGUCHI S, NISHI Y, SAKAI Y, TAKAYANAGI R, HAJI M, NAWATA H: Serum dehydroepiandrosterone (DHEA) and DHEA-sulfate (DHEA-S) in Alzheimer's disease and in cerebrovascular dementia. Endocr J 43: 119-123, 1996. 